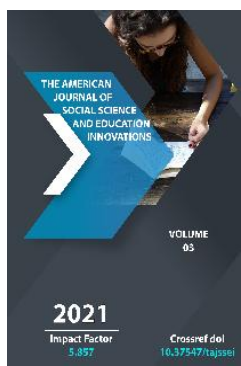

\title{
Application Of Systematic Approach To The Analysis Of Terminological Systems
}

\author{
Rikhsieva Lola Azimjanovna \\ Senior Teacher, UzSWLU, The Department Of English Translation Theory And Practice, \\ Tashkent City, Uzbekistan
}

\begin{abstract}
Journal Website:
http://theamericanjour

nals.com/index.php/taj

ssei

Copyright: Original content from this work may be used under the terms of the creative commons attributes
\end{abstract}

- $1: \ldots . . .-1$

\section{ABSTRACT}

The objective of this paper is to analyze the peculiarities of terminological system in oil exploration geology and engineering geology. In particular, we identify the terms selected both by their motivation and by their non-motivation through investigating of English and Uzbek terms in oil exploration and engineering as the branches of geology. We adopt a method of description and classification as systematic approach, dividing the terms into pure-motivated we disclose them as nuclear units and other special nominative units we distinguish them as unmotivated terms. The goal of this systematic approach is to facilitate the most efficient means of generating consistent and optimum results in terminological system.

\section{KEYWORDS}

Terms, terminological system, motivated, semi-motivated and unmotivated, nuclear, periphery. level. The perfect scientific language defines the

\section{INTRODUCTION}

All aspects of the development and sustainable development of human society thrive through scientific discoveries. Today, science is rising to the level of international and interethnic development. An important factor in the development of science is the integration of international knowledge which allows scientific research to reach a deeper

existence of an international scientific community and serves as the basis for science. Terminology is the basis of scientific language and helps to form world scientific knowledge at all stages of development. Terminology plays a very important role in any field of knowledge, so it is impossible to study and 
develop any field of knowledge without mastering special vocabulary. In addition to the need to study narrow specialized areas in any our professional activity, we must clarify the field of terminology, namely, the science that studies terms. Terminology is a set of terms in a particular science or field, as well as a system of terms about their formation, composition, and function. In the early period of the history of terminology, which lasted until the early 1960s, the basic concept of "terminological system" was formed. The terminological system, in turn, arises when any field of science or activity is sufficiently developed to have its own theory, to demonstrate basic concepts. One of the differences of terminological system from terminology is that terms are selected by experts in a particular field and in some cases specific words or phrases, as well as terms derived from another language which are chosen to describe the theory of that field. Terminological issues were applied in linguists' research works such as G.O. Vinokur, A.S. Gerd, V.M. Leichik, D.S. Lotte, K. Kageura, S. Jacobson, Sh. Abdullaeva G. Abdurahmonov, S.A. Azizov, X.D. Paluanova, D.X. Kadirbekova, O.S. Akhmedov. Although there is a lot of research done in the field of terminology, there are also some unexplored problems related to the nature of the term, the study and solution of which implies a new approach to modern linguistic trends.

\section{MATERIAL AND METHODS}

According to V.M. Leichik, the terminological system is the result of the regulation of terms, due to the fact that it can fully meet the requirements for terms. Based on scientific research, it should be noted that "terminology" is a set of self-formed lexical units, and "terminological system" is a hierarchical system of terms, regulated by terminologists (Leichik 2001:54-55). In the terminological system each term occupies a specific place. Among the concepts in the whole system, the term has its own concept and is defined by its place in the system. Outside of this system, the term loses its distinctive features and within the linguistic system (not terminologically) it can express its national and cultural affiliation, as well as linguistic categories such as polysemy, metaphorical, figurative, expressive, emotional, connotative. For example, the polysemy is occurred when the word coal (тоикуцми)is used as a term in the sphere of geology, in the process of translation in petrography - a rock (тоғ жинси), in mining a mineral (фойдали қазилма) (Куо Kageura 2000:45-46). In order to form terminological system of certain sphere, the terminological system must be based on the classification of concepts, and on the basis of classification schemes, there must be a need to distinguish term-specific features in the terminological system. (Lotte 1968:119). According to the typology of terms which on the basis of all classifications is the various individual characteristics of the terms - content (composition), formal, functional, linguistic and non-linguistic. (Khakimova 2013: № 4,11361142)

\section{DISCUSSION AND RESULTS}

One of the classification of terms can be selected both by their motivation and by their non-motivation. According to this type of classification, there are terms that can be explained their meaning or sometimes cannot be explained in the certain sphere. Lexical units are characterized by motivation. It can be divided into fully motivated, semimotivated and generally unmotivated terms. When we say terms are motivated, we mean that the terminological prototype that created the term is literally based. In the research of Sh. N. Abdullaeva the concept of 
terminological field is revealed. According to the research, at the center of the terminological field is the unification of terms as signs of special concepts; there is a terminological system consisting of a set of interconnected and intersecting term-spheres. As the nuclear unit of each term-sphere, there are terms with features such as intelligibility, clarity, unambiguousness, definiteness, structure. It also distinguishes other special nominative units that form the periphery of the terminological field and do not fully meet the requirements for terms.(Abdullaeva 2017: Volume 8, № 4, 920-929) For example, in oil exploration geology, engineering geology, the glossary and contextual meanings of the term pump-насос are not characterized by inconsistencies and the semantic structure of the mud / slash pump- бурғилаш насоси,ejector / air pump- эжектор (хаво) насоси, triplex pump- уч цилиндрли насос are terms that are fully motivated which replaced in nucleus of term-sphere. The greatest interest of terminology researchers is focused on unmotivated terms because they are less professionally-semantically compatible. For example, the name of the equipment (object) used in geology in the oil and gas industry, the term “Фонтанная арматура" (Fountain armature) in Russian and “Фонтансимон арматура" in Uzbek may be partially clear to those who are not experts in the oil industry, but the naming of this term as an analogue of the term Christmastree in English makes it difficult for both terminologists and experts in the field to explain the meaning of the term and what it is about. In such cases, the terms are considered unmotivated and in some cases such kind of terms are replaced by motivated terms. For example, the term

Christmastree can be changed to the Wellhead equipment term combination.
Instead of drawworks or winch mostly hoist (лебёдка)транссмисион вал is used in the field of pure term or wirelinegrab, gutter as synonyms. Backpressure - орқа ёки қарши босим and Plunger - плунжер, турткич in Uzbek translation of motivational terms, in the first case the literal translation does not lead to the appearance of a semantic part that contradicts the definition of this reality, in the second case the transliteration to indicate the English equivalent method and is professionally-semantically appropriate in extraction of oil, we can undoubtedly include such terms in the motivated layer. Terms such as ram- химоя плашкаси (мустахкам мастик материал), fishing- mутиш ишлари олиб бориш, fish- нефть қудуғидаги бегона npeдмem (strange object in oil well), downtime- оддий бурғилаш (sample drilling) are not professionally-semantically suitable for the oil industry and can be included in the list of generally unmotivated terms.

According to the description and classification of the terminological system in oil industry and through analysis we draw out the classification scheme in several layers. For example, petroleum and oil terms in English are the main nuclear units of the oil exploration geology and engineering geology terminology, then hoist, wirelinegrab, gutter deem a pure as motivated terms are located on level of nuclear units, wellhead equipment as semi-motivated term which located on level of near the periphery and christmastree, fish, downtime as non-motivated terms which located as far from the periphery. Practical analysis confirms that there is no clear boundary between peripheral components, however, the placement of terms in the periphery is characterized by semantic 


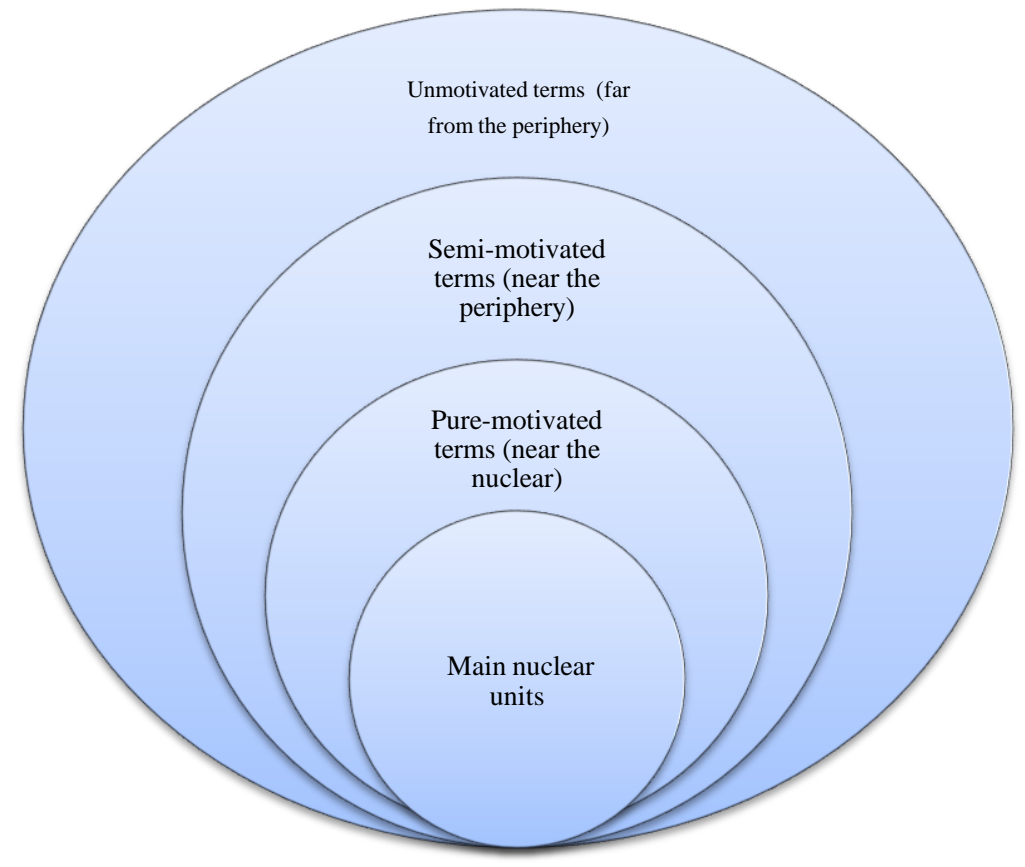

Chart 1. Classification scheme of the terminological system with several layers

\section{CONCLUSION}

The subject of general terminology theory includes the study of the formation and use of special words, the transfer of knowledge gained by mankind through them, the improvement of existing terminological systems, the search for new terms and optimal ways to create their systems, the universal features of terminology. Each term has a clear scientific definition, along with other terms in the same field. Terms, unlike everyday words, have the same meaning in the terminological system of a single field and the same terms can be terms of different fields of knowledge, but this is homonymy, not polysemy. The term fish has been used in oil industry as a term, changing its nature. Typically, industry professionals define terms based on their professional activities, which do not fully define the terms, but reflect their important features. The terminology of general lexicon has been used for many years

and this phenomenon demonstrates the relationship between language and terminology. This process is also evident in the integral connections between general literary vocabulary and terminological vocabulary. The transition of common words to the system of terminological system has been identified as the existence of common usage. As a rule, words derived from a common literary language into a terminological system are adapted to express a particular scientific concept, gaining the status of a scientific term. Application of a systematic approach gives an opportunity to analyze the terms and classify them into motivated as pure terms which related to nuclear units, semi-motivated and unmotivated terms as peripheral units in terminological system. 


\section{REFERENCES}

1. Abdullaeva. Sh.N.2017 "The using of financial economic terms in sphere of treasury" RUDN Journal of Language Studies, Semiotics and Semantics, Volume 8, № 4, 920-929.

2. Antia, Bassey Edem.2000 "Terminology and language planning: an alternative framework of practice and discourse" Philadelphia, John Benjamins Publishing Company.

3. Kageura.K.2000 "Handbook of Terminology- Terminology and lexicography" Volume 1, 45-46, Philadelphia, John Benjamins Publishing Company.

4. Khakimova. G.G.2013 "A term as a linguistic unit, a term within the framework of the theory of a term field". Bulletin of the Bashkir University, № 4, 1136-1142.

5. http://bulletin-

bsu.com/arch/files/2013/4/41_4329_Hakim ova-Fpage+1136+.pdf.

6. Leichik.V.M.1993. "Application of the system approach for the analysis of terminological systems // Study of terminology. №1-2, 23-26, Moscow Lyceum.

7. Leichik. V.M.2001 "The problem of consistency in Russian terminology // Scientific and technical terminology" Issue 2, 54-55. Moscow.

8. Lotte D.S.1968 "Formation and spelling of three-element scientific and technical terms", 119 .
9. Maleeva.V.E.1992."Social and cultural component of the semantics of terminological vocabulary" 198, Moscow.

10. Motin.M.V. "Motivated and unmotivated terminological units of oil and gas topics in the structure of the concept "oil" (based on the material of modern English)UDC:Section81Linguistics.Languag es.

https://nlrs.ru/toprofessionals/Cataloque/u $\mathrm{dk} /$ UDC81.htm.

\section{Appendix}

Acts of geological sciences covered by the study

Act of the President of the Republic of Uzbekistan "On measures to organize the activities of the University of Geological Sciences in the system of the State Committee for Geology and Mineral Resources" № PR4740 08.06.2020(Uzbekistan)

1965: The Science and Technology Act and the creation of the Institute of Geological Sciences(UK) 